\title{
Disputed Identifications: Jews and the Use of Biblical Models in the Barbarian
}

\section{Kingdoms $^{1}$}

\author{
Walter Pohl
}

\begin{abstract}
[Accepted manuscript of the chapter published in: Barbarians and Jews. Jews and Judaism in the Early Medieval West, ed.
\end{abstract} Yitzhak Hen and Thomas F.X. Noble (Turnhout 2018) 11-28].

The people of Israel represented an epistemological challenge to late antique and early medieval Christians. Christian authors employed several strategies to detach the spiritual and historical promise of the chosen people of the Old Testament from the Jews of their own day. Under the new covenant, the populus Christianus was rooted in the many gentes that it came to comprise, and the Old-Testament rhetoric of election was reinterpreted in this context. In medieval Europe, the Church came to be organised in Landeskirchen, within the frontiers of the respective states and realms. One influential current of thought has assumed that this lapse into Christian particularism was due to the pervasive influence of 'Germanic' ethnic thinking that superseded Christian universalist attitudes and created separate Gentilkirchen. ${ }^{2}$ However, Peter Brown has more convincingly described the development of these 'microChristendoms' in the post-Roman West in the context of 'the Rise of Western Christendom': 'Often singularly ill-informed about their neighbours, or deeply distrustful of them, the leaders of each "micro-Christendom" fastened with fierce loyalty on those features that seemed to reflect in microcosm, in their own land, the imagined, all embracing macrocosm of a world-wide Christianity'. ${ }^{3}$ Particular political, ethnic and ecclesiatical identities were seen as reflecting all the traits that made the Church universal, and often, as reflecting them better than other Churches. The Israel of the Old Testament as a model acquired a rather ambivalent significance, as Mayke de Jong has argued:

\footnotetext{
${ }^{1}$ The research leading to these results was supported by the Austrian Research Fund (FWF) and conducted in the context of the SFB Grant 'VISCOM', F42-G18 and the Project P27804-G16. I am grateful to Gerda Heydemann, Graeme Ward and Nicola Edelmann for help and suggestions. A first brief synthesis of the argument is found in Walter Pohl, 'Christian and barbarian identities in the early medieval West: introduction', in Post-Roman Transitions: Christian and Barbarian Identities in the Early Medieval West, ed. by Walter Pohl and Gerda Heydemann, Cultural Encounters in Late Antiquity and the Middle Ages, 14 (Turnhout: Brepols, 2013), pp. 146.

${ }^{2}$ Arnold Angenendt, 'Der eine Adam und die vielen Stammväter. Idee und Wirklichkeit der Origo gentis im Mittelalter', in Herkunft und Ursprung: historische und mythische Formen der Legitimation, ed. by Peter Wunderli (Sigmaringen: Hiersemann, 1994), pp. 27-52; Lutz von Padberg, ,Unus populus ex diversis gentibus. Gentilismus und Einheit im früheren Mittelalter', in Der Umgang mit dem Fremden in der Vormoderne: Studien zur Akkulturation in bildungshistorischer Sicht, ed. by Christoph Lüth et al. (Köln: Böhlau, 1997), pp. 155-93, at p. 184. The word 'gentil' was used in German scholarship for the ethnic worldview of the early Germans; see Walter Pohl, 'Gentilismus', in Reallexikon der Germanischen Altertumskunde 2nd edition, 11 (Berlin: De Gruyter, 1998), pp. 91-101.

${ }^{3}$ Peter Brown, The Rise of Western Christendom: Triumph and Diversity, AD 200-1000, 2nd ed. (Oxford:

Blackwell, 2003), pp. 13-20 and 355-79, here at p. 364.
} 
The idea that all the early medieval 'micro-Christendoms' in the West perceived themselves as so many 'New Israels' has recently attracted some justified criticism, but all the same, the Old Testament histories and their authoritative tales of kings past were a constant source of inspiration and trepidation for early medieval rulers and their learned courtiers. ${ }^{4}$

How, then, did the Old Testament affect the role of the early medieval gentes after the dissolution of the Roman Empire? ${ }^{5}$ Obviously, it could be used as a resource of identification in the early medieval kingdoms of the Latin West. That, however, was not simply a question of styling one or another people as God's elect. More importantly, the Bible prominently featured ethnic distinctions. The Old Testament could help to interpret and legitimize the new world of ethnically defined kingdoms in Europe. The Bible, more than any other text in Western culture, served as a 'Great Code’ (as Northrop Frye has called it), a master-narrative that could inspire and empower a great variety of codes and narratives that gave meaning to political, social and cultural practices. ${ }^{6}$ This was not a straightforward operation; the Great Code was so successful precisely because it could be used for diverse aims and arguments. This also applies to its treatment of ethnicity. Apart from more or less subtle stylizations of single chosen peoples within a biblical matrix (which were relatively rare in the early Middle Ages $^{7}$ ), what mattered most was that the Old Testament encouraged using ethnic distinctions as a structuring principle of the social world. This is a field that has awaited comprehensive treatment. $^{8}$

Indeed, studies of late antique and early medieval identities have often juxtaposed ethnicity and Christianity. Ethnicity was seen as a particularist, barbarian, predominantly military, and

\footnotetext{
${ }^{4}$ Mayke de Jong, 'Ecclesia and the early medieval polity', in Staat im frühen Mittelalter, ed. by Stuart Airlie, Helmut Reimitz and Walter Pohl, Forschungen zur Geschichte des Mittelalters, 11 (Vienna: Verlag der Österreichischen Akademie der Wissenschaften, 2006), pp. 113-32, at p. 120.

${ }^{5}$ For the historical context, and for the role of ethnicity in early medieval Europe, see Walter Pohl, 'Introduction: Strategies of identification. A methodological profile’, in Strategies of Identification: Ethnicity and Religion in Early Medieval Europe, ed. by Walter Pohl and Gerda Heydemann, Cultural Encounters in Late Antiquity and the Middle Ages, 13 (Turnhout: Brepols, 2012), pp. 1-64; Pohl, 'Christian and barbarian identities'. ${ }^{6}$ Northrop Frye, The Great Code: The Bible in Literature (Chicago: Routledge \& Kegan Paul, 1982).

${ }^{7}$ Mary Garrison, 'The Franks as the New Israel? Education for an identity from Pippin to Charlemagne', in The Uses of the Past in the Early Middle Ages, ed. by Yitzhak Hen and Matthew Innes (Cambridge: Cambridge University Press, 2000), pp. 114-61; Gerda Heydemann and Walter Pohl, 'The rhetoric of election - 1 Peter 2.9 and the Franks', in Religious Franks, ed. by Rob Meens et al. (Manchester: Manchester University Press), pp. 13-31.

${ }^{8}$ For some relevant approaches to the subject, see Arno Borst, Der Turmbau von Babel: Geschichte der Meinungen über Ursprung und Vielfalt der Sprachen und Völker, 4 vols (Stuttgart: Hiersemann, 1957-63; repr. München: dtv, 1995); Adrian Hastings, The Construction of Nationhood: Ethnicity, Religion and Nationalism (Cambridge: Cambridge University Press, 1997); Anthony D. Smith, Chosen Peoples: Sacred Sources of National Identity (Oxford: Oxford University Press, 2003); The Calling of the Nations: Exegesis, Ethnography, and Empire in a Biblical-Historic Present, ed. by Mark Vessey, Sharon V. Betcher, Robert A. Daum and Harry O. Maier (Toronto/Buffalo/London: University of Toronto Press, 2011). More work has been done on early medieval Britain, for instance, Daniel Anlezark, Water and Fire: The Myth of the Flood in Anglo-Saxon England (Manchester/New York: Manchester University Press, 2006); Stephen J. Harris, Race and Ethnicity in AngloSaxon Literature (New York/London: Routledge, 2003), pp. 45-129.
} 
rather crude way of forming communities, largely based on oral traditions. Christianity, on the other hand, was regarded as universal, Roman, literate, mainly representing civilian attitudes, and thus as a much more sophisticated way of constructing communities. In line with this model, European history has often been portrayed as a struggle between universal and national principles. The same model was used to contrast Jewish ethnic particularism with universal Christianity. ${ }^{9}$ It is of course true that many Christians of the period, influenced by Paul or Augustine, promoted a universalist, supra-ethnic perspective. The dichotomy between ecclesia and populus Christianus vs. the gentes is well attested in the sources. However, as Mayke de Jong has maintained, 'rather than following the dichotomies created by early medieval authors, these should be made into central topics of research'. ${ }^{10}$ The Bible provided detailed models for different forms of ethnic identification. If we are seeking to understand why ethnic rule gained some legitimacy in post-Roman Europe, this connection should be explored. To a considerable extent, the political role of ethnicity in Latin Europe was not a barbarian import. ${ }^{11}$ Far from being antithetical to the universal Church, it became possible precisely through Christianity and within the Church. The simple fact that (apart from a few rather transient steppe empires) only Christian realms achieved long-term supra-regional rule in medieval Europe substantiates this claim.

In the Old Testament, ethnicity plays a key role. God's covenant was with a people, the people of Israel. ${ }^{12}$ Belonging to the chosen people implied accepting an enormous moral responsibility. More often than not, God's own people strayed from the covenant, and it was duly punished. The moral and ritual drama in which God's protection and His punishment were enacted often unfolded in scenarios of ethnic conflict. Surrounding peoples, from the Egyptians and Philistines to Assyrians and Babylonians, served as instruments of God's wrath. One may debate whether such an 'ethnic view' of the Ancient Orient is correct, and what exactly it meant in the course of the complex history of the Hebrew Bible. Regardless of

\footnotetext{
${ }^{9}$ For a critique of this approach, see John M. G. Barclay, 'Universalism and Particularism: Twin Components of both Judaism and Early Christianity', in A Vision for the Church: Studies in Early Christian Ecclesiology in Honour of J. P. M. Sweet, ed. by Markus Bockmuehl and Michael G. Thompson (Edinburgh: T\&T Clark, 1997), pp. 207-24; Caroline Johnson Hodge, If Sons, then Heirs: A Study of Kinship and Ethnicity in the Letters of Paul (Oxford and New York: Oxford University Press, 2007); David G. Horrell, “"Race“, „Nation“, „People“: Ethnic Identity-Construction in 1 Peter 2. 9', New Testament Studies, 58 (2011), 123-43.

${ }^{10}$ De Jong, 'Ecclesia', p. 118.

${ }^{11}$ Walter Pohl, 'Introduction: ethnicity, religion and empire', in Visions of Community in the Post-Roman World: The West, Byzantium and the Islamic World, 300-1100, ed. by Walter Pohl, Clemens Gantner and Richard Payne (Farnham/Burlington: Ashgate, 2012), pp. 1-23.

${ }^{12}$ For instance, Leviticus 20. 26: You must be holy to me because I, the Lord, am holy, and I have set you apart from the other peoples to be mine; Jeremiah 31. 31-34: I will make a new covenant with the whole nation of Israel after I plant them back in the land (...) I will put my law within them and write it on their hearts and minds. I will be their God and they will be my people.
} 
that, the question pertinent to our purposes is what Christians in the Latin West could learn from the Bible about ethnicity. In the Old Testament, early medieval readers could easily distinguish a landscape of gentes and reges not unlike their own, and very much unlike the Roman Empire.

The manifold meanings of ethnicity in the Hebrew Bible are a rather vexed question. ${ }^{13}$ In biblical scholarship, the question of ethnicity has often been regarded as an unwanted element that could obscure the spiritual message both of Judaism and Christianity. Debates implicitly or explicitly revolved around the question whether the Hebrew Bible presented an ethnocentrist vision. Jewish and Christian apologists tended to treat the role of ethnicity with reserve, emphasizing Jewish openness to all nations and Christian universality. ${ }^{14}$ In a sense that paradoxically reverses the debate of the first Christian centuries when the Christians had been accused (for instance, by Celsus) that they 'did not have continuity with Judaism, and their laws had no traditional sanction, and that therefore they lacked national legitimacy., ${ }^{15}$ Judith Lieu and Denise Buell have discussed the extensive use of ethnic terms for the early Christians. ${ }^{16}$ In response, it has been argued that terms such as the Greek genos or ethnos or the Latin gens cannot truly be considered ethnic if they appear in a Christian context. ${ }^{17}$

The debate in Biblical Studies also reflects a tendency in much contemporary historical and anthropological research to regard ethnicity as a bad thing that is best explained away as modern projection, a cultural construction or an imagined community. ${ }^{18}$ Erich Gruen has forcefully argued that Greeks, Romans, and even Jews 'did not, on the whole, trouble themselves about the purity of the bloodline, and, unlike moderns, they probably did not

\footnotetext{
${ }^{13}$ Otto Bächli, Israel und die Völker. Eine Studie zum Deuteronomium (Zürich/Stuttgart: Zwingli-Verlag, 1962); Christiana van Houten, The Alien in Israelite Law (Sheffield: Bloomsbury T\&T Clark, 1991); Kenton L. Sparks, Ethnicity and Identity in Ancient Israel: Prolegomena to the Study of Ethnic Sentiments and Their Expression in the Hebrew Bible (Winona Lake, IN: Eisenbrauns, 1998); Ethnicity and the Bible, ed. by Mark G. Brett

(Boston/Leiden: Brill, 2002); Steven Grosby, Biblical Ideas of Nationality: Ancient and Modern (Winona Lake, IN: Eisenbrauns, 2002); Smith, Chosen Peoples.

${ }^{14}$ See, for instance, Joseph Ratzinger, Die Einheit der Nationen - Eine Vision der Kirchenväter (Salzburg: Anton Pustet, 22005 [ $\left.\left.{ }^{1} 1971\right]\right)$.

${ }^{15}$ Louis H. Feldman, Jew and Gentile in the Ancient World (Princeton: Princeton University Press, 1993), p. 197.

${ }^{16}$ Judith M. Lieu, Christian Identity in the Jewish and Graeco-Roman World (Oxford: Oxford University Press, 2004); Denise K. Buell, Why this New Race? Ethnic Reasoning in Early Christianity (New York, NY: Columbia University Press, 2005).

${ }^{17}$ Aaron P. Johnson, Ethnicity and Argumentation in Eusebius' Praeparatio Evangelica. Oxford Early Christian Studies (Oxford: Oxford University Press, 2006), pp. 25-54.

${ }^{18}$ Walter Pohl, 'Comparing Communities - the Limits of Typology', in History and Anthropology 26, 1 (2015), Special Issue: Visions of Community: Comparative Approaches to Medieval Forms of Identity in Europe and Asia, ed. by Andre Gingrich and Christina Lutter, 18-35.
} 
agonize much about ethnicity. ${ }^{, 19}$ As already becomes obvious in this concluding phrase of his argument, Gruen sets up a very narrowly defined model of ethnicity in order to demonstrate that it did not matter in Antiquity. Gruen's definition of ethnicity can only be deduced from the way in which he brushes away one type of evidence for ancient ethnicity after the other: Ethnicity is ‘indistinguishable from race' (p. 2); it presumes autochthony and can be excluded if any migrations even of distant forefathers appear in the sources (p. 3); it excludes intermingling (p. 4) or mixed marriages (p. 6); it not only implies a contempt for the inferiority of others, but that inferiority also has to be racially explained and sought in the blood, not in cultural customs (p. 8); if religion is seen as an important factor of identity it cannot be ethnic (p. 9); ethnicity must entail hostility towards other peoples (p. 10); it corresponds to a 'fixed nature, inherent in the people' (p. 12) in which one is 'trapped' and which does not allow any change of lifestyle (p. 11); and it is established by 'nature, not nurture' (p. 13). This is clearly a reductio ad absurdum of the concept of ethnicity. Nowadays, nobody would qualify for belonging to an ethnic group whose forebears ever migrated (or are believed to have migrated), or who wears jeans and drinks Coca-Cola, or who does not hate other ethnic groups and believes that their bad habits are in the blood.

His blunt conclusions aside, Gruen's argument is valuable because it challenges us to test definitions of ethnicity against the evidence. ${ }^{20}$ If we choose a weak definition that typically lists a number of features such as a common culture, a shared past, and a sense of solidarity, then it also applies to religious, civic, political, territorial and many other forms of identity, not only to ethnicity. ${ }^{21}$ I agree with Gruen that, heuristically speaking, ideas of common origin as a distinctive feature of ethnicity are more adequate. However, we should apply more realistic criteria to judge when such ideas can be assumed. The Latin, and to an extent also the Greek terminology is based on procreation (gens, genos/genus, natio) and clearly suggests common descent. Ethnos has a different etymology and a broader semantic range (for instance, it can also refer to a swarm of bees - but they are usually of common origin! - p. 1 and pp. 13-20). We cannot expect that notions of common origin are regularly made explicit in our sources. Why should they, if the author could expect that his audience would understand it that way? Even for us, there are enough clues to this implicit understanding in

\footnotetext{
${ }^{19}$ Erich Gruen, 'Did Ancient Identity Depend on Ethnicity? A Preliminary Probe', in Phoenix 67:1/2 (2013), 122.

${ }^{20}$ For the following, see Pohl, 'Strategies of Identification'.

${ }^{21}$ This is where the very sound argument in Horell, "Race”, "Nation”, "People”, becomes unwieldy at the very end: 'One might also question whether such constructionist definitions of ethnic identity imply that any religious group might be defined as an ethnic group, if it exhibits all or most of the above characteristics. I think the answer to this would be affirmative, at least potentially.' (p. 141).
} 
the sources. The Bible, for instance, provides a clear genealogy of peoples derived from the sons of Noah. In most cases, we can still clearly decipher when terms such as ethnos or gens are used for peoples and carry an ethnic meaning, and when they are employed in a more metaphorical sense. In some cases, ethnic terms and ethnonyms may only approximately correspond to scholarly definitions of ethnicity. But on the whole, they allowed distinguishing between peoples and thus provided orientation in a complex social world. It is this function of placing social groups within a largely coherent system of distinctions, however fuzzy it may have been at the margins, which can meaningfully be called 'ethnicity'. Ethnicity can then be regarded as a system of distinctions between more or less analogous social groups which are generally perceived as being naturally constituted by their common origin.

As a next step, we should differentiate between ethnicity as a relational and cognitive system, on the one hand, and ethnic identity/ethnic group as it emerges from the social practice of identification, on the other. That may also be helpful to judge whether the early Christians were in any sense an ethnic group. Distinguishing themselves from Greeks and Jews, they could be classed as a tertium genus in a matrix that included ethnicity. Some Christians may have found that reassuring, while others, such as Tertullian, refused this ethnic dimension of their identity. ${ }^{22}$ The insistent use of ethnic language tells us a lot about the early Christians' search for identity, which we could not appreciate if we decided that this language was not ethnic at all. But there would be little heuristic value in arguing that the Christians actually were an ethnic group.

Of course, one will rarely find a group that is only ethnic, without having to rely on further identifications with a territory, a political unit and/or a religious cult. Identities on the ground were necessarily composite. Ethnic identifications could matter more or less in them. More often than not, they included a strong religious dimension. It is therefore doubtful whether it makes much sense to debate whether Jewish identity was either religious or ethnic.

Distinguishing between ethnic and religious identifications is of course a legitimate level of analysis; but the distinction has its limits, for both modes of identification are often closely intertwined, especially in the Jewish case. Ethnic language may be used to describe religious affiliations, and vice versa. That is not a flaw in the language ('no stability holds in the vocabulary ${ }^{23}$ ). It reflected the actual dynamic of Jewish identity, which was both ethnic and

\footnotetext{
${ }^{22}$ See the different interpretations in Horell, “"Race”, “Nation”, “People”, p. 133, and Gruen, 'Did Ancient Identity Depend on Ethnicity', p. 19.

${ }^{23}$ Gruen, 'Did Ancient Identity Depend on Ethnicity’, p. 1.
} 
religious. It surely makes sense to discuss whether religious or ethnic modes of identification prevailed at a certain time or were more important to certain groups of people, although these identifications may not always be clearly distinguishable. ${ }^{24}$

All societies develop symbolic codes for the construction and delimitation of communities, which is an elementary operation in the production of social realities. As the sociologist Bernhard Giesen has shown, this distinction between insiders and outsiders can, in some cases, be relatively pragmatic and straightforward, depending on the degree of familiarity with and the social distance towards strangers. In other cases, the delineation between ingroup and out-group can be charged with additional meanings (for instance, good and bad; high and low; civilized and barbarian), which will increase its impact. ${ }^{25}$ Both ethnicity and religion offer powerful mechanisms of inclusion/exclusion that can be easily combined to reinforce the symbolic charge. Certainly, Judaism and Christianity provided codes of collective identity which carried highly symbolical significance. Nothing less than the question of salvation or condemnation depended on membership in the group, whether it was 'the people of Israel' or 'the Church'.

But that is not the bottom line. After all, many ethnic or religious groups had their exclusive gods who afforded protection, and sometimes also promised salvation, only to members. What was special about both Judaism and Christianity is that they not only drew highly charged boundaries between them and the rest of the world, the goyim, the gentes or the pagans, but at the same time, they dynamized these identities. These affiliations only became meaningful along the high-tension line of the history of salvation. To enjoy the benefits of the covenant, one not only had to belong to the people of Israel, one needed to accept an elaborate system of beliefs and follow a set of rigid moral and ritual rules. The Christians had similarly ambitious expectations; it was not enough to be baptized and to follow the standard religious procedures to attain salvation. Thus, as envisaged by Augustine, an invisible 'City of God' emerged alongside the civitas terrena, which only comprised part of the Christians or of their clerics. The boundaries between inside and outside were constantly renegotiated. Insiders could become apostates even without meaning to; outsiders could be drawn into Christian

\footnotetext{
${ }^{24}$ Sparks, Ethnicity, p. 328 and p. 325, acknowledging the 'dynamic interplay between ethnic and religious modes of identity', but still pointing to a decision: 'Throughout the [post-exilic] period that we have examined, ethnicity seems to have played a secondary role to Israelite and Judean concerns about religious identity'. See also Love L. Sechrest, A Former Jew: Paul and the Dialectics of Race (London and New York: T.\&T. Clark, 2009).

${ }^{25}$ Bernhard Giesen, 'Codes kollektiver Identität’, in Religion und Identität: im Horizont des Pluralismus, ed. by Werner Gephart and Hans Waldenfels (Frankfurt am Main: Suhrkamp, 1999), pp. 13-43, at 14.
} 
communities, sometimes without fully realizing the implications of this move. The God of the Hebrew Bible could call outsiders into his flock, and he could certainly use foreign peoples as his instruments. The Christian God extended this call with the goal to bring all the gentes into the fold, and he continued to use pagan peoples to punish Christian sinners. To complicate matters, the Christians essentially continued to use the symbolic language of the Hebrew Bible to define belonging and otherness, although their cosmological outlook was quite different.

This biblical matrix was inescapably dynamic: which of the gentes, and who among them would heed the call for salvation and join the Christian populus? Who would relapse, and how could one be part of the civitas Dei, in accordance with the unfathomable will of God? Which of the gentes would be able to attain divine protection by its faith and its deeds? Such a dynamic sense of the mysterious workings of divine favour and intervention among the nations could not but shape contemporary perceptions of the meaning of ethnic communities, and impinge on their political uses. From a Christian point of view, it implied strong moral responsibilities because even the sins of some members could put God's protection at risk. ${ }^{26}$

Of course, the Christian appropriation of the 'code of collective identity' of the Hebrew Bible also created real problems for the perception of the Jews. ${ }^{27}$ The people of Israel had not only been driven from the centre of its sacred topography into the diaspora, but, in Christian eyes, the Jews had been dislodged from the symbolic centre of the history of salvation. Generations of Christian authors had to cope with the overwhelming evidence of the Old Testament about the unique role of the Jews as the chosen people. The 'Israel according to the Flesh' (1 Corinthians 10.18) of the Christian era was therefore written out of contemporary sacred history, and the place of the Jews in the Christian order of things remained contested. ${ }^{28}$ They were perceived both as a gens and as a heretical sect that had strayed from God, for instance, in the Histories of Gregory of Tours. ${ }^{29}$

\footnotetext{
${ }^{26}$ Heydemann and Pohl, 'The rhetoric of election'.

${ }^{27}$ Feldman, Jew and Gentile; Robert Chazan, Fashioning Jewish Identity in Medieval Western Christendom (Cambridge: Cambridge University Press, 2004); Israel Jacob Yuval, Two Nations in Your Womb: Perceptions of Jews and Christians in Late Antiquity and the Middle Ages (Berkeley/Los Angeles/London: University of California Press, 2007).

${ }^{28}$ But see Paula Frederiksen, Augustine and the Jews: A Christian Defense of Jews and Judaism (New York: Doubleday, 2008).

${ }^{29}$ Avril Keely, 'Arians and Jews in the Histories of Gregory of Tours', Journal of Medieval History, 23/2 (1997), 103-15.
} 
The transformation of the ethnic structure of the Old Testament left a kind of 'floating gap' which had to be filled with other identifications of God's people. This turned out to be a key element in the uses of the Old Testament discourse of collective identity by late antique and early medieval authors. ${ }^{30}$ Early Christians had appropriated the notion of the chosen people of Israel and styled themselves as the 'new' Israel. The first letter of Peter (I Peter 2. 9-10), building on Exodus 19. 5, informed the early Christians: 'But you are a chosen people, a royal priesthood, a holy nation, a people of His own, so that you may proclaim the virtues of the one who called you out of darkness into his marvellous light. You once were not a people, but now you are God's people', ${ }^{31}$ a passage often discussed in later exegesis. Paul's epistle to the Romans (Romans 9. 6-13) contends: 'For not all who are descended from Israel belong to Israel, and not all are children of Abraham because they are his descendants [...] This means that it is not the children of the flesh who are the children of God, but the children of the promise are reckoned as descendants.' Thus, it is divine choice and not biological pedigree that truly matters. ${ }^{32}$ Still, genealogy remained an argument, and the notion that the Christians (but also the pagans) were physically descended from Abraham continued to be a matter of polemic. The story of Jacob and Esau, with its bitter struggle between brothers, provided one focus of debate; Christians and Jews could identify each other with the Edomites. ${ }^{33}$

This polemic often implied the deliberate use of ethnic terminology for the early Church. Denise Buell has collected many instances, for example, Justin the Martyr’s Dialogue with Trypho the Jew, written c. 160 A.D., which defines Christians as 'the true and spiritual Israelite ethnos' and 'the genos of Judah, Jacob, Israel and Abraham'. ${ }^{34}$ Of course, to hold the people of Israel as a model for Christian identity was also problematic. ${ }^{35}$ As the Church expanded, allegorical interpretations became one way out of the dilemma. In regarding the Ecclesia as a whole as the new Israel, the accent shifted from the notion of gens, which carried ethnic and genealogical connotations, to the civic concept of populus as developed in

\footnotetext{
${ }^{30}$ See Gerda Heydemann, 'Biblical Israel and the Christian gentes. Social metaphors and concepts of community in Cassiodorus' Expositio psalmorum', in Strategies of Identification: Ethnicity and Religion in Early Medieval Europe, ed. by Walter Pohl and Gerda Heydemann, Cultural Encounters in Late Antiquity and the Middle Ages 13 (Turnhout: Brepols, 2013), pp. 143-208.

${ }^{31}$ Vos autem genus electum, regale sacerdotium, gens sancta, populus adquisitionis [...] qui aliquando non populus, nunc autem populus Dei. See Heydemann and Pohl, 'The rhetoric of election'.

${ }^{32}$ Yuval, Two Nations, pp. 12-13.

${ }^{33}$ Yuval, Two Nations, pp. 3-10. Later, fictive biblical genealogies became common in Anglo-Saxon England, where they appeared at the time of King Alfred, in the late ninth century: Anlezark, Water and Fire, pp. 241-90.

${ }^{34}$ Buell, Why this New Race?, p. 99.

${ }^{35}$ Gerda Heydemann, 'People(s) of God? Biblical exegesis and the language of community in late antique and early medieval Europe’, in Meanings of Community across Medieval Eurasia, ed. by Eirik Hovden, Christina Lutter and Walter Pohl (Leiden: Brill, 2016), pp. 27-60.
} 
the Roman empire. ${ }^{36}$ The populus Romanus consisted of many gentes and thus provided a model of inclusion that was more suited to the needs of the Church triumphant than the direct analogy with the People of Israel.

The Church Fathers therefore generally argued against any direct historical or genealogical identification of the Christians with Israel, or their definition as a gens. To give just a few examples among many: Ambrose wrote explicitly that 'we, who are assembled from different peoples, cannot usurp the designation of one gens. ${ }^{37}$ And Augustine, in his Enarrationes in Psalmos, comments upon Psalm 82: ${ }^{38}$ 'But Israel must be understood here as the semen of Abraham, about which the Apostle says, And if you belong to Christ, then you are Abraham's descendants, heirs according to the promise (Galatians 3. 29): not Israel according to the flesh, about which he says, Look at the people of Israel (Videte Israel secundum carnem, I Corinthians 10. 18)'. More directly, the North African sixth-century author Verecundus states that the Christians are not a gens like the others 'who live gathered together in one place, like the gens Iudaeorum [...] or like any other, the Gothic or the Parthian or the Herul people [...] But we are dispersed across the whole world' ${ }^{39}$ His choice of stable settlement as the criterion by which to distinguish the Jews from the Christians has a rather ironic sense to it clearly, it is the Jews of the Old Testament rather than those of the diaspora who are being discussed.

Between the fourth and sixth centuries, the notion of an all-encompassing populus Christianus, shaped after the model of Rome, could serve as a basis for the ideology of a Christian Empire. As the idea of an all-encompassing Christian Rome faded, space for the

\footnotetext{
${ }^{36}$ For the distinction of gens and populus as models of peoplehood in Late Antiquity, see Patrick J. Geary, The Myth of Nations: the Medieval Origins of Europe (Princeton, N.J.: Princeton University Press, 2002), p. 55. ${ }^{37}$ Ambrose, Explanatio super psalmos XII, 36. 7, ed. by Michael Petschenig and Michaela Zelzer, Corpus scriptorum ecclesiasticorum Latinorum 64 (Vienna: Verlag der Österreichischen Akademie der Wissenschaften, 1999), p. 75: Nos de diversis populis congregati vocabulum unius gentis non possumus usurpare [...] Christi populus diceremur.

${ }^{38}$ Augustinus, Enarrationes in psalmos, ed. by Eligius Dekkers and Johannes Fraipont, 3 vols, Corpvs Christianorvm Series Latina, vol. 39 (Turnhout: Brepols, 1956), ps. 82, 5, p. 1142: Israel autem hic debet intelligi utique semen Abrahae, cui dicit Apostolus, Ergo Abrahae semen estis, secundum promissionem haeredes (Galatians 3. 29): non Israel secundum carnem, de quo dicit, Videte Israel secundum carnem (I Corinthians 10. 18). See also vol. 40, ps. 104, 1, 5, p. 1538. I owe this and the following passage to Gerda Heydemann.

${ }^{39}$ Verecundus Iuncensis, Commentarii super cantica ecclesiastica, 22, ed. by Roland Demeulenaere, Corpvs Christianorvm Series Latina, 93 (Turnholt: Brepols, 1976), p. 40, about Deuteronomy 32. 21: Et ego zelabo in non gente: Non gentem posuit Christianos, qui non sicut ceterae gentium nationes uno in loco habitant congregati, sicut gens videlicet Iudaeorum (ibi sexcenta milia fuerunt adunata) vel sicut quaelibet, Gothica vel Parthica seu Herula. Sed nos dispersi per totum diffusae latitudinis orbem.
} 
accommodation of Christian gentes within the flock opened up. ${ }^{40}$ If a new people could be converted, this was seen as a sign of divine providence. Avitus of Vienne wrote to Clovis on the occasion of his baptism: 'Deus gentem vestram per vos ex toto suam faciet'. ${ }^{41}$ In this view, conversion of a pagan people represented divine election. Saint Patrick called the Irish 'plebem nuper venientem ad credulitatem, quam sumpsit Dominus ab extremis terrae'. ${ }^{42}$ Pope Gregory the Great likewise referred to divine election of the Angles in his letter to Augustine: 'Scio enim quia omnipotens Deus per dilectionem tuam in gente quam eligi voluit magna miracula ostendit'. ${ }^{43}$ From the Pauline and Augustinian points of view, conversion would have rendered ethnicity quite meaningless. But, in fact, having been called upon by divine providence could also reinforce ethnic identities. Thus, ideas of election and the subtle comparison of one's own people to biblical parallels became current in the early medieval kingdoms. Bede, writing about the period when the Angles and Saxons were pagans and did had not yet received Christian teachings from the Britons, concludes: 'Sed non tamen divina pietas plebem suam, quam prescivit, deseruit, quin multo digniores genti memoratae praecones veritatis, per quos crederet, destinavit' ${ }^{44}$ Providence could bring a people closer to salvation but also subject it to hardships. Gildas, a fifth/sixth-century British author, paralleled the misfortunes of Israel - 'a people that was peculiarly His own among all nations, a royal stock, a holy gens' - with those of the Britons of his day. ${ }^{45}$ Divine election could never be taken for granted, as the Old Testament clearly demonstrated; it depended on proper conduct, especially of kings, bishops and priests, and on God's mercy.

Divine intervention in favour of a Christian gens after the model of the Old Testament was sought in battles, just as Constantine and Clovis had reputedly been granted victory by God. In the late sixth century, John of Biclaro directly ascribes a victory of the Visigoths over the Franks under King Reccared to God's intervention and compares it to the victory of Gideon over the Midianites, one of many Old Testament examples. ${ }^{46}$ This also becomes clear in the

\footnotetext{
${ }^{40}$ See Gerda Heydemann, Exegese, Rhetorik und politische Gemeinschaft im 6. Jahrhundert. Studien zum Psalmenkommentar des Cassiodor (PhD thesis, Vienna 2013; publication in preparation).

${ }^{41}$ Avitus of Vienne, Opera quae supersunt, ed. Rudolf Peiper, MGH AA 6.2, Berlin 1883, 76; englische Übersetztung: Letters and Selected Prose, transl. with an introd. and notes by Danuta Shanzer and Ian Wood, Translated Texts for Historians, 38 (Liverpool: Liverpool University Press, 2002), p. 373.

${ }^{42}$ Patricius, Confessiones, 38, ed. and trans. Allan B. E. Hood, St. Patrick: His writings and Muirchu's life (London: Phillimore, 1978), p. 30; Brown, Rise, p. 132.

${ }^{43}$ Gregorius Magnus, Registrum Epistularum, XI. 36, ed. by Dag Norberg, Corpvs Christianorvm: Series Latina 140a (Turnholt: Brepols, 1982), p. 926:.

${ }^{44}$ Beda, Historia Ecclesiastica, I. 22, ed. and trans. by Bertram Colgrave and Roger A. B. Mynors, Oxford Medieval Texts (Oxford: Clarendon Press, 1969), p. 68:.

${ }^{45}$ Gildas, De excidio Britanniae, 1. 13, trans. Michael Winterbottom (London: Phillimore, 1978), p. 15.

${ }^{46}$ John of Biclaro, 91, transl. with notes and introd. by Kenneth Baxter Wolf, Conquerors and chroniclers of early medieval Spain (Liverpool: Liverpool University Press, 1990), p. 77.
} 
early medieval liturgy of war. ${ }^{47}$ An early seventh-century liturgical manuscript at Reichenau asks the Lord to give victory to the kings of the Franks: 'You who are the only good king, the only one who can give, bestow victory on the kings of the Franks', as you have liberated Israel from the plagues of Egypt. ${ }^{48}$ The Missa pro principe preserved in the eighth-century Bobbio Missal invokes God's help for the prince with the words: 'So let him, oh Lord, by the right hand of your virtue always be the victor in triumph over all adversaries, as you once helped Moses' ${ }^{49}$ The Carolingian period witnessed systematic attempts to extend the liturgy of war to the Christian people in the entire kingdom; everybody should take part in prayers, litanies, fasting and processions for victory over the enemies. Regardless of whether the Carolingians (and the popes in the second half of the eighth century) initiated or only continued this practice and irrespective of its efficacy, the effort represented a clear attempt to extend the boundaries of an ethnic identity to a territorially defined population through the medium of Christian liturgy.

Christian kingdoms and peoples could aspire to divine favour and seek to model themselves, to varying degrees, on biblical precedent. ${ }^{50}$ Precisely how such a possibility shaped their identities is in many respects an open question. Yet on a deeper level, the Bible offered 'codes of ethnicity' implying that peoples could exercise collective agency. The biblical panorama of a world of gentes could legitimize the political role of ethnic identities in the history of Western Europe. It was not the ethnocentric model of a single chosen people surrounded by enemies that became productive in the West. Rather, a relatively stable plurality of Christian peoples and nations emerged, all of which could compete for the grace of God.

Of course, the wide horizons of Christian proselytizing sanctioned the idea of a multitude of essentially equivalent peoples, all of whom were called to salvation. Yet, the idea that God, as creator of the whole world, had called many or all gentes is already prominent in the Hebrew

\footnotetext{
${ }^{47}$ Walter Pohl, 'Liturgie di guerra nei regni altomedievali’, Rivista di Storia del Cristianesimo, 5/1 (2008), 2944; Michael McCormick, Eternal Victory: Triumphal Rulership in Late Antiquity, Byzantium and the Early Medieval West (Cambridge: Cambridge University Press, 1986).

${ }^{48}$ Qui sulus es rix bonus, sulus pristans, prista Francurum rigibus victuriam ut liberati a ribelli suo saluentur quia tu sulus pius omnipotens eternus qui liberasti israhel de omnibus malum egipto: Cod. Augiensis CCLIII, published in Alban Dold, Das Palimpsestsakramentar im Codex Augiensis CXII. Ein Meßbuch ältester Struktur aus dem Alpengebiet, Beuron: Druckerei und Verlag der Kunstschule der Erzabtei Beuron, 1925), p. 71.

${ }^{49}$ Ita eum, Domine, per dexteram virtutis tui contra omnes adversarius semper esse iubeas cum triumphis victorem, sicut condam auxiliatus es Moysen. See Mary Garrison, 'The Missa pro principe in the Bobbio Missal', in The Bobbio Missal: Liturgy and Religious Culture in Merovingian Gaul, ed. by Yitzhak Hen and Rob Meens, Cambridge Studies in palaeography and codicology 11 (Cambridge: Cambridge University Press, 2004), pp. 187-205, with English translation of the mass (pp. 201-03).

${ }^{50}$ See Yitzhak Hen, 'The Uses of the Bible and the perception of kingship in Merovingian Gaul', Early Medieval Europe, 7 (1998), 277-89, and other contributions in the same issue.
} 
Bible. ${ }^{51}$ A number of the pertinent passages were commented upon in early medieval exegesis. In Genesis 17. 5, the Lord tells Abraham: 'I will make you the father of a multitude of nations'. Paul's Epistle to the Romans (4. 16-17) echoes this passage: 'The promise may be certain to all the descendants - not only to those who are under the law, but also to those who have the faith of Abraham, who is the father of us all (as it is written, "I have made you the father of many nations”)'. Psalm 22. 27-29 is even more inclusive: 'Let all the people of the earth acknowledge the Lord and turn to him! Let all the nations worship you! For the Lord is king and rules over the nations. All of the thriving people of the earth will join the celebration and worship'. Christian commentators saw that as an expression of the Christian message. For instance, Cassiodorus concludes that the preceding passage, 'All you descendants of Israel, stand in awe of Him!', thus must also refer to all peoples: 'The semen of Israel does not mean that of one people, but is understood as the fullness of all peoples, which clearly the Church must unite'. ${ }^{2}$

While the Pauline vision required that this multitude of nations be merged into a Christian whole, the post-Roman Christian world consisted of many gentes. Most scholars assume that this happened because ethnic realities in the post-Roman world were stronger than the universal vision of the Church. Yet, ethnic 'realities' themselves were still in the course of formation in the fifth and sixth centuries. Why did kingdoms of the Franks and Lombards replace Roman rule, and not kingdoms of Gaul and Italy? These ethnic identifications only evolved gradually in the Christian kingdoms. Christian discourse must have played a part here. One of the key texts in this respect is Prosper's De vocatione omnium gentium, a midfifth-century treatise against Pelagianism. ${ }^{53}$ Pelagius had argued that the road to salvation was in the personal moral responsibility of each individual. His opponents, first and foremost Augustine, tried to show that on the contrary, it was only by God's grace that one could attain

\footnotetext{
${ }^{51}$ This is not the place to go into the question of the different historical layers of the Hebrew Bible and their contexts, which may have had different implications for the role of ethnicity in the respective texts. See Horst Seebass, 'Identität als Volk des einen Gottes. Identität im Alten Testament', in Religion und Identität: im Horizont des Pluralismus, ed. by Werner Gephart and Hans Waldenfels (Frankfurt am Main: Suhrkamp, 1999), pp. 87-104.

${ }^{52}$ Semen Israel non unius populus significatur, sed cunctarum gentium cognoscitur plenitudo, unde constat Ecclesiam colligendam. Cassiodorus, Explanation of the Psalms, transl. Patrick G. Walsh, vol. 1 (Mahwah, NJ: Paulist Press, 1990), pp. 235-40. See Heydemann, Exegese.

${ }^{53}$ Prosper, De vocatione omnium gentium, ed. by Roland J. Teske and Dorothea Weber, Corpus scriptorum ecclesiasticorum Latinorum, 97 (Vienna: Verlag der Österreichischen Akademie der Wissenschaften, 2009). See Alexander Hwang, Intrepid Lover of Perfect Grace: The Life and Thought of Prosper of Aquitaine (Washington: Catholic University of America Press, 2009). For a fuller discussion of Prosper, see Pohl, 'Post-Roman Transitions: Introduction', pp. 20-21.
} 
salvation. ${ }^{54}$ However, there was a problem with this reasoning. Why did God's grace work so unevenly among individuals, so that some could not even receive His teachings? Prosper argued that God could not have called all individuals equally, but that he would eventually call all peoples to salvation. Some might receive the calling earlier and others later, but none would be left out. Prosper adduces several biblical verses to show that God 'has never denied the gifts of his goodness to any of the gentes'. The diversity of the gentes is a heavenly gift; all of them belong to God in their quality as peoples. All nations are called to salvation, but it depends on God's grace which of its members can attain it. On the other hand, the Old Testament could supply examples that one sinner could provoke punishment for the whole people, as in the case of Achan in the Book of Joshua (Joshua 1. 7-9).

Thus, salvation depended as much on the community as on the individual. God's grace could work through representatives, but the entire people would be involved. This flexible concept of ethnicity could also be useful in describing the complex realities of early medieval kingdoms. Omnes Franci, in the eighth century, could mean a few hundred political leaders, tens of thousands of warriors fighting in the Frankish army, or the whole population of the Frankish realm. ${ }^{55}$ Thus, when Frankish historiography speaks of the Franks, it often refers to only a part of them, those who represent the people. ${ }^{56}$ Early medieval ethnic language does not depict clearly delineated social groups, but a complex concept with multiple layers of significance.

Biblical discourse also gave eschatological meaning to enemies, even to the worst of barbarians. Examples of divine punishment abound in the Old Testament. One of the passages cited most frequently by late antique and early medieval authors is Psalm 83. 4, in which the enemies of Israel threaten to unite against the people of God. They say, 'Come on, let's annihilate them so they are no longer a nation (disperdamus eos de gente)! Then the name of Israel will be remembered no more'. Cassiodorus, as many other authors of the period, parallels this to the Antichrist threatening the Christians with extinction. ${ }^{57}$ But these passages were always also open to a more literal reading. Such models became important with the barbarian invasions from the late fourth century onwards, which were subtly integrated into

\footnotetext{
${ }^{54}$ For Pelagianism, see Robert A. Markus, The End of Ancient Christianity (Cambridge: Cambridge University Press, 1990), pp. 40-46.

${ }^{55}$ Walter Pohl, ‘Aux origines d'une Europe ethnique: Identités en transformation entre antiquité et moyen âge’, Annales: Histoire, Sciences sociales, 60/1 (2005), 183-208.

${ }^{56}$ See Helmut Reimitz, History, Frankish Identity and the Framing of Western Ethnicity, 550-850 (Cambridge: Cambridge University Press, 2015).

${ }^{57}$ Heydemann, Exegese.
} 
the Christian history of salvation. Christian apologists could not leave these disruptions of the Roman order unexplained. Following Old Testament models, it was easy enough to picture barbarian peoples as the 'scourge of God'. Salvian underlined the moral superiority of the conquering barbarians over the sinful Romans, and Pope Leo I interpreted the attacks of the Huns as divine punishment, an idea certainly inspired by the Old Testament. ${ }^{58}$ Interpretations could be controversial; for example, were the Goths and Huns (identified with the ancient Massagetes) the Gog and Magog of the visions of Ezechiel and the Apocalypse? ${ }^{59}$

In any case, all of these events were depicted in distinctly ethnic language; new names of peoples were identified with familiar names from the biblical and classical repertoire. Even derisive outside identifications would soon proudly be turned into elements of self-identity, an operation achieved by Christian intellectuals in the regna. Thus, Isidore, in his Gothic history, claims that the Goths were descended from the people of Gog, regardless of the apocalyptic context of that name. ${ }^{60}$ Authors who had come to feel at home in the post-Roman regna could employ various biblical identifications to flatter barbarian rulers, create consent among their Christian subjects, and define their own roles as instruments of God's will. ${ }^{61}$ Soon, they employed a wide range of biblical models. The biblical matrix made it easier for Christian subjects to accept their new rulers, and for bishops to collaborate with them. It is not unlikely that it also paved the way for the ethnic definition of the new realms. After all, these were gentes that had been received into the Christian fold.

Of course, ethnicity was neither a Jewish nor a Christian invention. Neither was it a constant phenomenon; the significance of ethnic identities for the shaping of large communities varied greatly throughout the course of history. I have argued that the Bible attached an intricate set of meanings to ethnicity, thus providing a wealth of options to give shape to ethnic communities, and to legitimize the claims of those who ruled in their name. Arguably, the development of ethnic states (and in the long run, modern nations) in most parts of Europe

\footnotetext{
${ }^{58}$ Leonis Papae I epistularum collectiones, ed. by Edvardvs Schwartz, Acta Conciliorvm Oecvmenicorvm 2, 4 (Berolini: de Gruyter, 1932), p. 65; Huns as virga furoris Dei: Isidorus, Historia Gothorum, 28-29, ed. by Theodor Mommsen, MGH AA 11 (Berlin: Weidmann, 1894) pp. 268-95, p. 279.

${ }^{59}$ Mark Humphries, 'Gog is the Goth: biblical barbarians in Ambrose of Milan’s De fide', in Unclassical Traditions: Alternatives to the Classical Past in Late Antiquity, ed. by Richard Flower, Christopher Kelly and Michael Williams (Cambridge: The Cambridge Philological Society, 2010), pp. 44-57; Veronika Wieser, 'Roms wilde Völker. Grenzüberschreitungen und Untergangsstimm(ung)en im letzten Jahrhundert des römischen Imperiums‘, in Völker der Endzeit: Apokalyptische Vorstellungen und politische Szenarien, ed. by Wolfram Brandes, Felicitas Schmieder and Rebekka Voss (Berlin and New York: de Gruyter, 2016) pp. 23-50.

${ }^{60}$ Isidorus, Historia Gothorum, 1, p. 268.

${ }^{61}$ See Yitzhak Hen, Roman Barbarians: The Royal Court and Culture in the Early Medieval West (London and New York: Palgrave-Macmillan, 2007).
} 
was the paradoxical result of the early medieval attempt to create a Christian community guided by spiritual resources, inspired by the sense of urgency and the reluctance to compromise which such an enterprise required. The rich and ambiguous Jewish experience, as recounted in the Old Testament, provided scripts for a wide variety of changes and constellations, helping to channel the contingency of events in a post-classical age into a meaningful political landscape. In doing so, it charged ethnic identifications with providential significance, validating political strategies that sought to endow the new kingdoms with ethnic distinctiveness while remaining attached to the larger social whole of Latin Christendom. 